\title{
PENGARUH MENYUSUI SECARA EKSKLUSIF TERHADAP INVOLUSI UTERI PADA IBU NIFAS DI BPM YEFI MARLIANDIANI RUNGKUT SURABAYA TAHUN 2018
}

\section{The Effect Of Exclusive Breastfeeding On Uterin Involution In Nifas Mothers at BPM Yefi Marliandiani Rungkut Surabaya Year 2018}

\author{
Indria Nuraini ${ }^{1}$, Nyna Puspita Ningrum ${ }^{2}$, Retno Setyo Iswati ${ }^{3}$ \\ Prodi D III Kebidanan Universitas PGRI Adi Buana Surabaya \\ (nurainiindria@gmail.com)
}

\begin{abstract}
ABSTRAK
Latar Belakang : Masa Nifas merupakan periode pengawasan pada ibu post partum, yang berlangsung dari persalinan sampai 6 minggu setelah melahirkan. Pada masa ini terjadi pemulihan Organ Reproduksi kedalam sebelum hamil, salah satunya adalah Uterus. Proses kembalinya ukuran uterus seperti sebelum hamil disebut juga dengan Involusi Uteri. Pada periode ini sering mengalami kegawatdaruratan atau komplikasi yaitu tidak terjadinya Involusi dengan normal yang berakibat terjadinya perdarahan. Upaya untuk mengantisipasi perdarahan Post Partum dapat dilakukan dengan pemberian atau juga dengan menstimulasi keluarnya oksitosin. Salah satu cara untuk menstimulasi keluarnya oksitosin dengan Menyusui bayinya secara Eksklusif.

Tujuan penelitian : tujuan penelitian ini adalah untuk mengetahui pengaruh Menyusui secara Eksklusif terhadap Involusi Uteri Pada Ibu Nifas.

Metode : Penelitian ini menggunakan metode analitik observasional dengan pendekatan Cross Sectional. Variabel Independen dalam penelitian ini adalah Menyusui secara Eksklusif, sedangkan Variabel Dependen adalah Involusi Uteri. Penelitian ini dilakukan di BPM Yefi Marliandiani pada tahun 2018. Populasi penelitian ini adalah Ibu Nifas. Tehnik sampling yang digunakan Purposive sampling dengan jumlah sampel 40 responden. Uji statistik yang digunakan adalah Chi Square.

Hasil penelitian : didapatkan bahwa sebagian besar Involusi Uteri sesuai dengan umur masa nifas dengan menyusui secara eksklusif sebesar $47,5 \%$ dan sebagian kecil Involusi Uteri tidak sesuai dengan umur masa nifas dan menyusui tidak secara eksklusif sebesar 20\%. Berdasarkan hasil analisa data dengan Chie Square didapatkan bahwa $p=0,003$ dengan tingkat kemaknaan $(\alpha=0,05)$, sehingga $p<\alpha$.

Kesimpulan : ada Pengaruh Menyusui secara Eksklusif terhadap Involusi Uteri di BPM Yefi Marliandiani Rungkut Surabaya.
\end{abstract}

Kata Kunci : Menyusui, Involusi Uteri, Ibu Nifas 


\begin{abstract}
Background : Postpartum period is a monitoring period in post partum mothers, which lasts from labor to 6 weeks after delivery. During this period there is recovery of the reproductive organs into before pregnancy, one of which is Uterus. The process of returning uterine size such as before pregnancy is also called Uteri Involution. In this period, there are often emergency or complications, namely the occurrence of a normal Involution which results in bleeding. Efforts to anticipate Partum Post bleeding can be done by giving or also by stimulating oxytocin release. One way to stimulate the release of oxytocin by breastfeeding her baby exclusively.

The purpose : The purpose of this study was to determine the effect of Exclusive Breastfeeding on Uterine Involution in Nifas Mothers.

Method: This study used anmethod observational analytic with aapproach Cross Sectional. Independent variables in this study are exclusively breastfeeding, while the dependent variable is female involution. This research was conducted at BPM Yefi Marliandiani in 2018. The population of this study was Ms. Nifas. The sampling technique used was Purposive sampling with a sample of 40 respondents. The statistical test used is Chi Square.

The results of the study : it was found that most Uteri Involution according to the age of postpartum with exclusive breastfeeding amounted to $47.5 \%$ and a small portion of Uteri Involution did not match the age of postpartum and breastfeeding not exclusively by 20\%. Based on the results of data analysis with Chie Square, it was found that $p=0.003$ with a significance level $(\alpha=0.05)$, so that $p<\alpha$.

Conclusion: There is an Exclusive Effect of Breastfeeding on Uterine Involution in BPM Yefi Marliandiani Rungkut Surabaya.
\end{abstract}

Keywords: Breastfeeding, Uterine Involution, Mother Nifas

\title{
PENDAHULUAN
}

WHO mengemukakan bahwa 500.000 perempuan meninggal setiap tahun akibat komplikasi kehamilan dan melahirkan. Sebagian besar kematian terjadi selama atau segera setelah melahirkan. Penyebab kematian terbanyak pada ibu adalah Perdarahan, Eklampsia, dan Infeksi Post Partum (Manuaba, 2010)

Menurut Data Kementerian Kesehatan 17 Agustus 2017 di Republika.co.id mengungkapkan bahwa angka kematian ibu turun dari 4.912 kasus tahun 2016 menjadi 1.712 kasus pada tahun 2017 semester I. Sedangkan berdasarkan SUPAS tahun 2015 Angka Kematian Ibu di Indonesia masih cukup tinggi mencapai 305/100.000 KH. Menurut Profil Dinas Kesehatan Provinsi Jawa Timur Tahun 2015 menjelaskan bahwa angka Kematian Ibu Propinsi Jawa Timur tahun 2015 mencapai 89,6/100.000 KH, 84,8/100.000 KH AKI untuk Wilayah Surabaya. Penyebab Kematian Ibu di Jawa Timur yaitu 31\% Eklampsia, 25\% Perdarahan, Infeksi 6\%, Jantung 12\% dan lain-lain 26\%. Meskipun jumlah kejadian perdarahan Post Partum di Jawa Timur terdapat penurunan tetapi perlu untuk diantisipasi(Kesehatan and Jawa, 2015) 
Upaya untuk mengantisipasi perdarahan Post Partum dapat dilakukan dengan pemberian atau juga dengan menstimulasi keluarnya oksitosin. Hormon oksitosin sangat berperan dalam proses involusi uterus. Proses Involusi akan berjalan dengan bagus jika kontraksi uterus kuat (Cunningham et al., 2014). Oksitosin dapat diperoleh dengan berbagai cara baik melalui oral, intra-muscular, pemijatan yang merangsang keluarnya hormone oksitosin maupun dengan menyusukan bayinya secara kontinu.

Isapan pada puting susu merangsang pelepasan prolaktin dan oksitosin. Prolaktin akan merangsang produksi ASI, sedangkan oksitosin akan merangsang mioepitel di seputar alveoli yang akan berkontraksi dan memompa ASI keluar serta merangsang kontraksi uterus. Oksitosin disini berfungsi mengendalikan terjadinya perdarahan dengan memperbaiki kontraksi dan retraksi serat myometrium. Oleh karena itu upaya mempertahankan kontraksi uterus melalui menyusui merupakan bagian penting dalam perawatan Post Partum (Mursyida A.W, 2010).

Asuhan pada periode setelah melahirkan sangat penting. Tidak hanya untuk keberlangsungan hidup saja, tetapi juga untuk masa depan ibu dan bayi yang baru lahir. Perubahan besar terjadi selama periode ini yang dapat menentukan kesejahteraan dan potensi masa depan yang sehat. Pemantauan dan Asuhan pada masa Post Partum di fokuskan pada pemantauan Involusi Uteri, Proses Laktasi dan Kesehatan Ibu dan Bayi(Mursyida A.W, 2010). Berdasarkan latar belakang diatas maka peneliti ingin melakukan penelitian berjudul Pengaruh Menyusui Secara Eksklusif Terhadap Involusi Uteri Pada Ibu Nifas.

\section{METODE PENELITIAN}

Metode yang digunakan dalam penelitian ini adalah analitik observasional, dengan pendekatan cross sectional. Variabel independen dalam penelitian ini adalah Menyusui secara Eksklusif. Variable dependen dalam penelitian ini adalah Involusi Uteri. Populasi pada penelitian ini adalah Ibu Nifas 2 Jam Post Partum yang melahirkan pada bulan Mei sampai dengan September 2018 yang berjumlah 40 ibu Post Partum. Tehnik pengambilan Sampel Purposive Sampling, sehingga sampel dalam penelitian ini ibu Post Partum yang melahirkan pada bulan Mei sampai dengan September 2018 di BPM Yefi Marliandiani yang berjumlah 40 responden.

Alat pengumpulan data pada penelitian ini adalah menggunakan lembar observasi, dimana peneliti akan melakukan pemeriksaan dan didokumentasikan pada lembar observasi yang telah disediakan. Metode pengumpulan data yang peneliti gunakan adalah data primer yaitu lembar observasi, sedangkan data sekunder adalah data identitas ibu hamil yang didapatkan dari buku KIA atau Kohort Ibu.

Teknik pengolahan data dalam penelitian ini adalah : Editing, Coding, Scoring, Data entry dan Tabulating. Analisis data pada penelitian ini adalah Chi Square, dengan membandingkan antara yang menyusui dan tidak menyusui terhadap proses involusi uteri. 


\section{HASIL DAN PEMBAHASAN}

Tabel 1 Distribusi Frekuensi Pengaruh Umur terhadap Involusi Uteri

\begin{tabular}{|c|c|c|c|c|c|c|}
\hline \multirow[t]{2}{*}{ Umur } & \multicolumn{4}{|c|}{ Involusi Uteri } & \multirow[t]{2}{*}{ Total } & \multirow{2}{*}{$\begin{array}{c}\text { Prosentase } \\
(\%)\end{array}$} \\
\hline & Sesuai & $\begin{array}{c}\text { Prosentase } \\
(\%)\end{array}$ & $\begin{array}{l}\text { Tidak } \\
\text { sesuai }\end{array}$ & $\begin{array}{c}\text { Prosentase } \\
(\%)\end{array}$ & & \\
\hline$<20$ tahun & 1 & 2,5 & 1 & 2,5 & 2 & 5 \\
\hline $20-35$ tahun & 11 & 27,5 & 17 & 42,5 & 28 & 70 \\
\hline$>35$ tahun & 7 & 17,5 & 3 & 7,5 & 10 & 25 \\
\hline Total & 19 & 42,5 & 21 & 52,5 & 40 & 100 \\
\hline
\end{tabular}

Berdasarkan tabel 1 didapatkan bahwa sebagian besar responden Involusi Uteri tidak sesuai pada usia 20 - 35 tahun sebesar 17 responden $(42,5 \%)$

Tabel 2 Distribusi Frekuensi pengaruh Paritas terhadap Involusi Uteri

\begin{tabular}{|c|c|c|c|c|c|c|}
\hline \multirow[t]{2}{*}{ Paritas } & \multicolumn{4}{|c|}{ Involusi Uteri } & \multirow[t]{2}{*}{ Total } & \multirow{2}{*}{$\begin{array}{c}\text { Prosen } \\
\text { tase } \\
(\%)\end{array}$} \\
\hline & Sesuai & $\begin{array}{c}\text { Prosentase } \\
(\%)\end{array}$ & $\begin{array}{l}\text { Tidak } \\
\text { sesuai }\end{array}$ & $\begin{array}{c}\text { Prosentase } \\
(\%)\end{array}$ & & \\
\hline Primipara & 8 & 20 & 9 & 22,5 & 17 & 42,5 \\
\hline Multi Para & 9 & 22,5 & 9 & 22,5 & 18 & 45 \\
\hline Grandepara & 2 & 5 & 3 & 7,5 & 5 & 12,5 \\
\hline Total & 19 & 47,5 & 21 & 52,5 & 40 & 100 \\
\hline
\end{tabular}

Berdasarkan tabel 2 didapatkan bahwa sebagian besar Involusi Uteri tidak sesuai pada primipara ataupun multipara sebanyak 9 responden $(22,5 \%)$ dan Involusi Uteri sesuai pada multipara 9 responden $(22,5 \%)$

Tabel 3 Distribusi Frekuensi Pengaruh IMD terhadap Involusi Uteri

\begin{tabular}{|c|c|c|c|c|c|c|}
\hline \multirow[t]{2}{*}{ IMD } & \multicolumn{4}{|c|}{ Involusi Uteri } & \multirow[t]{2}{*}{ Total } & \multirow{2}{*}{$\begin{array}{c}\begin{array}{c}\text { Prose } \\
\text { ntase } \\
(\%)\end{array} \\
\end{array}$} \\
\hline & Sesuai & $\begin{array}{c}\text { Prosentase } \\
(\%)\end{array}$ & $\begin{array}{l}\text { Tidak } \\
\text { sesuai }\end{array}$ & $\begin{array}{c}\text { Prosentase } \\
(\%)\end{array}$ & & \\
\hline $\begin{array}{l}\text { Tidak dilakukan } \\
\text { IMD }\end{array}$ & 0 & 0 & 2 & 5 & 2 & 5 \\
\hline Dilakukan IMD & 19 & 47,5 & 19 & 47,5 & 38 & 95 \\
\hline Total & 19 & 47,5 & 21 & 52,5 & 40 & 100 \\
\hline
\end{tabular}

Berdasarkan tabel 3 didapatkan bahwa sebagian besar Involusi Uteri tidak sesuai dan dilakukan IMD sebesar 19 responden $(47,5 \%)$.

Tabel 4 Tabulasi Silang Menyusui terhadap Involusi Uteri

\begin{tabular}{|c|c|c|c|c|c|c|}
\hline \multirow[t]{2}{*}{ Menyusui } & \multicolumn{4}{|c|}{ Involusi Uteri } & \multirow[t]{2}{*}{ Total } & \multirow{2}{*}{$\begin{array}{c}\text { Prosen } \\
\text { tase } \\
(\%)\end{array}$} \\
\hline & Sesuai & $\begin{array}{c}\text { Prosentase } \\
(\%)\end{array}$ & $\begin{array}{l}\text { Tidak } \\
\text { sesuai }\end{array}$ & $\begin{array}{c}\text { Prosentase } \\
(\%)\end{array}$ & & \\
\hline Eksklusif & 19 & 47,5 & 13 & 32,5 & 32 & 80 \\
\hline $\begin{array}{l}\text { Tidak } \\
\text { Eksklusif }\end{array}$ & 0 & 0 & 8 & 20 & 8 & 20 \\
\hline Total & 19 & 47,5 & 21 & 52,5 & 40 & 100 \\
\hline
\end{tabular}


Berdasarkan tabel 4 didapatkan bahwa sebagian besar Involusi Uteri sesuai dengan umur masa nifas dengan menyusui secara eksklusif sebanyak 19 responden (47,5\%). Berdasarkan hasil analisa data dengan Chie Square didapatkan bahwa $p=0,003$, dengan tingkat kemaknaan $(\alpha=0,005)$ dan $p<$ 0,005 sehingga Ho diterima dan H1 ditolak. Dari hasil uji analisis data tersebut dapat disimpulkan bahwa ada Pengaruh Menyusui terhadap Involusi Uteri.

Hasil Penelitian pada tabel 1 didapatkan bahwa sebagian besar responden Involusi Uteri tidak sesuai pada usia 20 - 35 tahun sebesar 17 responden (42,5\%). Dari hasil diatas, usia 20-35 tahun merupakan individu mencapai kondisi vitalitas yang prima sehingga kontraksi otot dan kembalinya alat-alat kandungan yang sangat baik dan cepat pada usia tersebut. Pada usia tersebut merupakan usia reproduksi sehat, yang berarti bahwa tingkat kesuburan perempuan dalam masa puncak yang ideal untuk terjadinya proses involusi uteri. Berdasarkan hasil penelitian Apriyanti menjelaskan bahwa usia 20-35 tahun merupakan kelompok reproduksi yang paling ideal dilihat dari aspek kesehatan. Sedangkan berdasarkan hasil penelitian Liana $\mathrm{D}$, menjelaskan bahwa usia sangat berkaitan dengan penurunan tinggi fundus uteri semakin tua usia seseorang maka semakin berkurang fungsi reproduksinya yang berarti bahwa semakin tua usia seseorang maka proses involusi uteri berjalan dengan lambat, dikarenakan oleh peningkatan jumlah lemak, penurunan elastisitas otot dan penurunan penyerapan lemak, protein dan karbohidrat(Mursyida A.W, 2010).

Berdasarkan hasil penelitian diatas maka terdapat kesenjangan antara teori dengan fakta bahwa proses involusi uteri berjalan lambat pada usia 20 - 35 tahun, hal ini dapat terjadi karena dipengaruhi oleh faktor psikologis, pendidikan ataupun pengalaman. Pendidikan dapat meningkatkan kematangan intelektual, yang berpengaruh terhadap wawasan, cara berfikir seseorang, baik dalam tindakan maupun cara pengambilan keputusan dan pembuatan kebijakan. Ibu dengan pendidikan tinggi akan lebih baik menerapkan dalam perawatan diri sehingga lebih cepat dalam pemulihan kesehatan proses involusi uteri(Maulana, 2009)

Hasil Penelitian Pada tabel 2 didapatkan bahwa sebagian besar Involusi Uteri tidak berjalan sesuai dengan umur masa nifas baik dari primipara ataupun multipara sebesar 22,5\% sebanyak 9 responden. Menurut Kartsar (2011) menyatakan salah satu faktor yang mempengaruhi Involusi Uteri adalah Paritas. Involusi Uteri pada ibu bersalin bervariasi, ibu dengan paritas tinggi proses Involusinya berjalan dengan lambat karena uterus mengalami peregangan. Semakin banyak jumlah anak maka semakin lambat proses Involusi Uteri, karena paritas yang tinggi terjadi adanya peregangan uterus yang maksimal sehingga terdapat penurunan elastisitas otot dan penurunan penyerapan lemak, protein dan karbohidrat(Mursyida A.W, 2010). Berdasarkan hasil penelitian diatas terdapat kesenjangan antara teori dengan fakta. Pada primipara dan multipara proses involusi uteri berjalan dengan lambat (tidak sesuai dengan usia post partum), hal ini terjadi disebabkan oleh faktor mobilisasi ataupun pemenuhan gizi/nutrisi pasca melahirkan. Gizi berfungsi mempercepat pengembalian alat-alat kandungan, membantu memperbaiki jaringan tubuh serta sebagai petahanan dasar pada ligamentum latum terhadap kuman dan juga untuk menghilangkan jaringan nerkotic. Status gizi yang baik akan menghindari terjadinya infeksi serta 
mempercepat involusi uteri(Uteri and Nifas, 2015). Mobilisasi membantu perbaikan sirkulasi, membuat pernapasan dalam dan menstimulasi kembalinya fungsi gastrointestinal normal. Dengan mobilisasi dini membantu proses involusi uteri dan mengurangi perdarahan abnormal(Mobilisasi et al., 2014).

Hasil Penelitian Pada tabel 3 didapatkan bahwa sebagian besar Involusi Uteri tidak sesuai dengan umur masa nifas dan dilakukan IMD ataupun Involusi Uteri sesuai dengan umur masa nifas dan dilakukan IMD sebesar 47,5\% sebanyak 19 responden. Salah satu upaya untuk merangsang kontraksi uterus adalah dengan cara memberikan ASI secara dini. Pada proses ini oksitosin memberikan peran merangsang kontraksi otot-otot myoepitel disekitar alveoli tetapi juga memberikan efek neuroendokrin, memproduksi analgetik, mengurangi respon stress, dan menyebabkan kontraksi uterus('IMD.pdf', no date). Berdasarkan hasil penelitian Roesli (2008) menjelaskan bahwa proses Inisiasi Menyusui Dini dimulai saat bayi merangkak di dada ibu, sentuhan tangan di putting susu dan hentakan kepala bayi didada ibu akan merangsang pengeluaran oksitosin(Roesli, 2000). Berdasarkan penelitian Purwarini (2011) didapatkan bahwa kelompok yang dilakukan Inisiasi Menyusui Dini memiliki peluang 25 kali untuk memiliki tinggi fundus uteri normal dibandingkan dengan kelompok yang tidak dilakukan Inisiasi Menyusui Dini('IMD.pdf', no date). Untuk responden yang Involusi Uteri tidak sesuai dengan umur masa nifas tetapi dilakukan IMD dapat terjadi karena disebabkan oleh Paritas yang tinggi, umur ibu ataupun dapat terjadi karena status gizi ibu ataupun karena membatasi dalam melakukan aktifitas.

Hasil Penelitian pada tabel 4 didapatkan bahwa sebagian besar Involusi Uteri sesuai dengan umur masa nifas dengan menyusui secara eksklusif sebesar 47,5\% sebanyak 19 responden dan sebagian kecil Involusi Uteri tidak sesuai dengan umur masa nifas dan menyusui tidak secara eksklusif sebesar $20 \%$ sebanyak 8 responden.

Berdasarkan hasil analisa data dengan Chie Square didapatkan bahwa $p=$ 0,003 , dengan tingkat kemaknaan $(\alpha=0,005)$ dan $p<0,005$ sehingga Ho diterima dan H1 ditolak. Dari hasil uji analisis data tersebut dapat disimpulkan bahwa ada Pengaruh Menyusui terhadap Involusi Uteri. Pada putting susu terdapat saraf-saraf sensori yang jika mendapat rangsangan (isapan bayi) maka akan timbul impuls menuju hipotalamus maka kelenjar hipofisis bagian depan akan mempengaruhi pengeluaran hormone prolaktin (ASI diproduksi) sedangkan pada kelenjar hipofisis bagian belakang akan mempengaruhi pengeluaran hormone oksitosin yang berfungsi untuk memacu otot polos yang ada di dinding alveoli dan dinding saluran susu. Sehingga ASI dipompa untuk keluar dan memacu kontraksi otot rahim dan involusi uterus berlangsung lebih cepat (Ii and Nifas, no date). Hal ini sejalan dengan penelitian yang dilakukan Reeder (1997) dan Pilleteri (1999) yaitu perilaku menyusui yang baik dapat membantu kontraksi uterus dan penurunan tinggi fundus uteri dengan respon hormonal oksitosin ke otak yang akan memperkuat kontraksi uterus. Menurut Lobbok (1999) menjelaskan bahwa menyusui meningkatkan pengeluaran oksitosin sehingga menghasilkan proses Involusi Uteri cepat dan mengurangi angka kejadian perdarahan post partum serta angka kejadian anemia post partum('IMD.pdf', no date). 


\section{SIMPULAN DAN SARAN}

\section{Simpulan}

Involusi Uteri pada ibu nifas di BPM Yefi Marliandiani Rungkut Surabaya yaitu tidak berjalan sesuai dengan umur masa nifas sebesar 21 responden $(52,5 \%)$ sedangkan untuk menyusui pada ibu nifas di BPM Yefi Marliandiani Rungkut Surabaya yaitu menyusui secara eksklusif sebesar 32 responden (80\%). Sehingga ada pengaruh antara menyusui secara eksklusif terhadap Involusi Uteri di BPM Yefi Marliandiani Rungkut Surabaya.

\section{Saran}

Bagi BPM Yefi Marliandiani Rungkut Surabaya dari hasil penelitian ini diharapkan dapat memberikan masukan kepada klien khususnya ibu nifas tentang pentingnya menyusui secara eksklusif bagi ibu dan bayinya. Bagi tenaga kesehatan diharapkan dapat saling bekerja sama dengan institusi pendidikan yang berkaitan tentang memberikan pendidikan kesehatan, dan konseling tentang pentingnya ASI Eksklusif bagi ibu dan bayi.

\section{DAFTAR PUSTAKA}

Apriliasari, D. 2015. 'Hubungan usia dan paritas dengan kejadian involusi ibu nifas di bps mojokerto'. http://www.repository.poltekkesmajapahit.ac.id/cgisys/suspendedpage.cgi Diakses tanggal 26 Desember 2018 jam 10.30 WIB

Cunningham, A. F. et al. 2014. "Williams Obstetrics 24 / E The premier reference in obstetrics for more than a century â $€$ " now even more relevant to today 'spractice".

https://www.mheducation.com.au/media/wysiwyg/AUS/Professional/booksell er/2014/may/Medical_May.pdf Diakses tanggal 20 Desember 2018 jam 11.00 WIB

Dinas kesehatan provinsi jawa timur. 2015."Profil Kesehatan jawa timur tahun 2015". www.depkes.go.id/resources Diakses tanggal 22 Desember 2018 jam $13.00 \mathrm{WIB}$

Manuaba, I. G. 2010.Obstetri dan Ginekologi. Jakarta: EGC.

Maulana, H. D. 2009 Promosi Kesehatan. Jakarta: EGC.

Mursyida A.W .2010. "Hubungan Umur Ibu dan Paritas dengan Pemberian ASI Eksklusif pada Bayi Berusia 0-6 Bulan di Puskesmas Pembina Palembang". https://www.academia.edu/9755086 Diakses tanggal 25 Desember 2018 jam $12.00 \mathrm{WIB}$

Sabrina, D.W. 2014. "Pengaruh Mobilisasi Dini Terhadap Penurunan Tinggi Fundus Uteri Pada Ibu Nifas di Paviliun Melati RSUD Jombang". http://journal.unipdu.ac.id:8080/index.php/eduhealth/article/view/456/403

Diakses tanggal 22 Desember 2018 jam 13.30 WIB

Revi, Agusvina. 2015 "Hubungan Inisiasi Menyusui Dini (IMD) terhadap Keberhasilan ASI Eksklusif di Posyandu Kelurahan Cempaka Putih Ciputat Timur" http://repository.uinjkt.ac.id Diakses tanggal 20 Desember 2018 jam 11.30 WIB

Roesli, Utami. 2000. Mengenal ASI Eksklusif. Jakarta: Trubus Agriwidya. https://books.google.co.id Diakses tanggal 26 Desember 2018 jam 09.00 WIB 